\title{
Acquired Loss of Renal Nuclease Activity Is Restricted to DNasel and Is an Organ-Selective Feature in Murine Lupus Nephritis
}

\author{
Natalya Seredkina and Ole P. Rekvig \\ From the Molecular Pathology Research Group, Institute of \\ Medical Biology, Faculty of Health Sciences, University of \\ Tromsø, Tromsø, Norway
}

An acquired loss of renal DNaseI promotes transformation of mild mesangial lupus nephritis into membranoproliferative end-stage organ disease. In this study, we analyzed expression profiles of DNaseI in other organs of lupus-prone $(\mathrm{NZB} \times \mathrm{NZW}) \mathrm{F} 1$ mice during disease progression to determine whether silencing of the renal DNaseI gene is an organ-specific feature or whether loss of DNaseI reflects a systemic error in mice with sever lupus nephritis. The present results demonstrate normal or elevated levels of DNaseI mRNA and enzyme activity in liver, spleen, and serum samples from $(\mathrm{NZB} \times \mathrm{NZW}) \mathrm{F} 1$ mice throughout all the stages of lupus nephritis. DNaseI activity was dramatically reduced only in kidneys of mice with sever nephritis and was the only nuclease that was down-regulated, whereas six other nucleases (DNaseII1 to 3, caspase-activated DNase, Dnase2a, and endonuclease G) were approximately normally expressed in kidneys, liver, and spleen. Loss of renal DNaseI was not accompanied by changes in serum DNaseI activity, suggesting independent mechanisms of DNaseI regulation in circulation and in kidneys and an absence of compensatory up-regulation of serum DNaseI activity in the case of renal DNaseI deficiency. Thus, silencing of renal DNaseI is a unique renal feature in membranoproliferative lupus nephritis. Determining the mechanism(s) responsible for DNaseI down-regulation might lead to the generation of new therapeutic targets to treat and prevent progressive lupus nephritis. (Am J Pathol 2011, 179:1120-1128; DOI: 10.1016/j.ajpath.2011.05.011)

Systemic lupus erythematosus (SLE) is an autoimmune disease characterized by production of a variety of autoantibodies to nuclear antigens. ${ }^{1}$ The formation and se- quential deposition of immune complexes (ICs) in visceral organs represents a basic pathogenic mechanism of the disease. ${ }^{2}$ The potentially most severe clinical manifestation of SLE is lupus nephritis, ${ }^{3}$ which is initiated through IC deposition in glomeruli, leading to kidney dysfunction and, finally, renal failure. ${ }^{4,5}$ However, progression of the disease varies in intensity. Some patients experience progression from the mild mesangial form to full-blown membranoproliferative nephritis, whereas others remain with a benign mesangial pattern throughout life. ${ }^{6,7}$

In a recent study, we observed that lupus nephritis in female $(\mathrm{NZB} \times \mathrm{NZW}) \mathrm{F} 1$ (BW) mice is a principally twostep organ disease. ${ }^{8}$ The early phase correlates with deposition of complexes of chromatin fragments and IgG in the mesangial matrix. Progression of the disease, which is characterized by deposition of large chromatin fragments in glomerular basement membranes (GBMs) and severe proteinuria, correlates with an acquired loss of renal DNasel mRNA and enzyme activity. Loss of DNasel, a dominant renal nuclease, ${ }^{9}$ correlates with reduced chromatin degradation during regular apoptosis in kidneys. ${ }^{10,11}$ In the case of impaired clearance of apoptotic cells, ${ }^{12}$ loss of DNasel may explain the increased presence of chromatin fragments in membranes and matrices of affected glomeruli. Binding of such fragments to GBMs is probably most facilitated by increased expression of matrix metalloproteases 2 and 9, observed in nephritic kidneys. ${ }^{13}$

Expression profiles of DNasel in other organs in BW mice during kidney disease progression have not been assayed. In sera, DNasel is reduced in mice with lupus

Supported by the Foundation for Health and Rehabilitation through the Norwegian Rheumatology Organization (project 2004/2/0250), by the Northern Norway Regional Health Authority Medical Research Program (grants SFP-100-04 and SFP-101-04), and by the University of Tromsø as a milieu support (O.P.R.).

Accepted for publication May 4, 2011.

Supplemental material for this article can be found at http://ajp. amjpathol.org or at doi: 10.1016/j.ajpath.2011.05.011.

Address reprint requests to Ole P. Rekvig, M.D., Ph.D., Molecular Pathology Research Group, Institute of Medical Biology, Faculty of Health Sciences, University of Tromsø, Tromsø N-9037, Norway. E-mail: olepr@uit.no. 
nephritis. ${ }^{14,15}$ The reason for this, however, is unclear. Either DNasel is down-regulated in organs responsible for secreting DNasel or serum DNasel is reduced just because of consumption during nephritis. Therefore, it is important to verify whether silencing of the renal DNasel gene is an organ-specific feature or whether it reflects a systemic error in BW mice with sever lupus nephritis.

The aim of the present study was, therefore, to determine i) whether loss of renal DNasel is unique to the kidney or occurs simultaneously in other organs as well, ii) whether silencing of renal DNasel is a selective process not involving other nucleases in defined stages of the disease, and iii) whether there is any compensatory up-regulation of DNasel or other nucleases in kidneys and other organs.

In this study, we examined DNasel expression in kidneys, livers, and spleens of BW mice at different stages of lupus nephritis. This allowed us to analyze for deviations in DNasel levels in one strongly producing organ (liver) and in one marginally producing organ (spleen). Published data have demonstrated that the liver is the main source of serum DNasel, ${ }^{16}$ whereas in the spleen, the amount of DNasel is very low. ${ }^{17,18}$ Both organs are also responsible for clearance of circulating $\mathrm{ICs}^{19,20}$ and participate in the pathogenesis of lupus nephritis in the case of defective chromatin degradation. Therefore, the data described in this study are important in informing whether the processes observed in the kidney are unique to DNasel or represent global systemic errors in the body.

The present results demonstrate that the amount of renal DNasel is reduced strictly in membranoproliferative (endstage) nephritis and that DNasel is the only nuclease that is down-regulated of seven analyzed nucleases [DNasel, DNasell1 to 3, caspase-activated DNase (CAD), Dnase2a, and endonuclease $\mathrm{G}$ (EndoG)]. Although dramatically reduced in the kidneys, DNasel is not reduced in the spleen or in the liver. Expression of the other six nucleases remained largely, but not absolutely, stable in spleen and liver throughout the observation period. These data may point to mechanisms responsible for silencing of the DNasel gene as a future causal therapeutic target to treat and prevent progressive lupus nephritis.

\section{Materials and Methods}

\section{Animals}

Female BW and BALB/c mice were purchased from HarIan Laboratories UK Ltd. (Blackthorn, UK). Ttreatment and care of the animals were in accordance with the guidelines of the Norwegian Ethical and Welfare Board for Research Animals, and the study was approved by the Institutional Review Board at the University of Tromsø.

\section{Collection of Samples from Groups of Mice}

Serum samples from BW mice were collected from prenephritic mice (group 1, $n=3$ ), mice with mesangial nephritis (group 2, $n=3$ ), and mice with membranoproliferative nephritis (group $3, n=6$ ). Sera were stored at $-20^{\circ} \mathrm{C}$. Degree of proteinuria was monitored weekly using sticks from Bayer Diagnostics (Bridgend, UK). Ani- mals were euthanized by $\mathrm{CO}_{2}$ suffocation. Kidneys, livers, and spleens were extirpated, cut, snap frozen, and i) fixed in RNAlater (Qiagen Nordic, Oslo, Norway) for further analysis of gene transcription, ii) fixed in $4 \%$ buffered depolymerized paraformaldehyde and embedded in paraffin for immunohistochemical (IHC) analysis, or iii) fixed in $8 \%$ buffered depolymerized paraformaldehyde for immune electron microscopy (IEM) (kidneys and livers only). ${ }^{21}$ The same samples were collected from sex- and age-matched BALB/c control mice.

\section{Double-Stranded DNA-Specific ELISA}

Murine double-stranded DNA (dsDNA)-specific antibodies were detected and titrated by standard indirect enzyme-linked immunosorbent assay (ELISA), as described in detail elsewhere. ${ }^{22}$

\section{IEM}

IEM was performed on murine kidney and liver sections as described previously. ${ }^{21}$ In short, sections were incubated with rabbit anti-mouse IgG (RaM IgG; Cappel, ICN Pharmaceuticals Inc., Aurora, $\mathrm{OH}$ ), followed by protein $\mathrm{A}$ conjugated with 5-nm gold particles (PAG-5 nm, University of Utrecht, Utrecht, The Netherlands) to detect in vivo-bound IgG autoantibodies. Micrographs were taken using a Jeol JEM-1010 transmission electron microscope (Jeol Ltd., Tokyo, Japan).

\section{IHC Analysis}

Endonucleases in kidneys and livers were detected using a Polink-2 Plus horseradish peroxidase detection kit (Golden Bridge International Inc., Mukilteo, WA), as described in detail elsewhere. ${ }^{10}$ DNasel was detected by DNasel-specific antibody (Santa Cruz Biotechnology Inc., Santa Cruz, CA) diluted 1:50 for kidney sections and 1:30 for liver sections. CAD and EndoG were detected by CAD-specific antibody (diluted 1:150 for kidney and 1:70 for liver) and by EndoG-specific antibody (diluted 1:100 for kidney and 1:70 for liver) from BioSite (San Diego, CA). Secondary antibodies and diaminobenzidine chromogen solution were used according to instructions provided in the kit. Sections were counterstained with hematoxylin and Scott's solution and were analyzed using an Olympus BX51 microscope (Olympus, Center Valley, PA).

\section{Immunoexpression Score}

To evaluate the degree of protein expression, we blindly quantified the intensity of staining in 10 view fields per each kidney and liver section. The immunoexpression score (IEXP-SC) was adapted from Richardsen et al ${ }^{23}$ : $I E X P-S C=A E X \times I S I$, where AEX is the percentage cellular area of expression and ISI is the immunostaining intensity (grades 1 to 3 ). The product gives a score from 0 to 300, expressed as follows: negative, IEXP-SC $=0$; weakly positive, IEXP-SC $=1$ to 100 ; moderately positive, IEXP-SC = 101 to 200; and strongly positive, IEXP-SC = 201 to 300. 


\section{Gene Expression Analysis}

Total RNA was isolated using the EZ1 RNA tissue mini kit (Qiagen). The quality of RNA was analyzed using the Agilent bioanalyzer and the RNA 6000 assay kit (Agilent Technologies Inc., Santa Clara, CA). cDNA was transcribed from $2 \mu \mathrm{g}$ of RNA using the cDNA archive kit (Applied Biosystems, Carlsbad, CA). For real-time PCR, we used the following predesigned TaqMan gene expression assays (Applied Biosystems): Dnase1, Mm01342389_g1; Dnase1l1, Mm00510102_m1; Dnase1l2, Mm00481868_g1; Dnase1l3, Mm00432865_m1; CAD, Mm00432822_ m1; Dnase2a, Mm00438463_m1; EndoG, Mm00468248_m1; endogenous control-mouse actin $\beta$, 4352933E; and TATA binding protein, Mm00446973_m1. The assays were performed using the $\mathrm{ABI}$ Prism 7900HT sequence detection system (Applied Biosystems). Expression levels were calculated using the $\Delta \Delta \mathrm{C}_{\mathrm{T}}$ method. Data are given as fold change compared with transcription in 12-week-old mice. The protocol for analysis of DNasel expression in spleens was modified owing to low expression levels. To detect mRNAs, we had to use a two times higher concentration of cDNA than we used for kidney and liver samples.

\section{DNase Radial Diffusion Assay to Determine Activity of Neutral $\mathrm{pH}-, \mathrm{Ca}^{2+}$-, and/or $\mathrm{Mg}^{2+}$-Dependent Endonucleases}

To evaluate DNase activity in kidneys, livers, spleens, and sera, a DNase radial diffusion assay was performed as described elsewhere. ${ }^{24}$ Ten milligrams of tissue was homogenized in DNase reaction buffer $(40 \mathrm{mmol} / \mathrm{L}$ Tris, $\mathrm{pH} 7.6,2 \mathrm{mmol} / \mathrm{L} \mathrm{CaCl}_{2}$, and $2 \mathrm{mmol} / \mathrm{L} \mathrm{MgCl}_{2}$ ) with $0.1 \%$ Triton X-100 (Roche Diagnostics GmbH, Mannheim, Germany). Cell debris was removed by centrifugation at $13,000 \times g$, and supernatant was stored at $-80^{\circ} \mathrm{C}$. Total protein amount was measured using BCA assay (Pierce Biotechnology, Rockford, IL). For analysis, tissue samples were thawed on ice, protein concentration was normalized for every tissue to be equal in all samples, and $2.5-\mu \mathrm{L}$ aliquots of tissue lysates were loaded into $1-\mathrm{mm}$ wells in a $1 \%$ agarose gel containing $50 \mu \mathrm{g} / \mathrm{mL}$ (for livers and spleens) or $100 \mu \mathrm{g} / \mathrm{mL}$ (for kidneys and sera) of calf thymus DNA (Sigma-Aldrich, St. Louis, MO) and $1 \mu \mathrm{g} / \mathrm{mL}$ of ethidium bromide in DNase reaction buffer. Serum samples were loaded directly to the gel after defrosting on ice. Recombinant human DNasel from Amersham Biosciences (Piscataway, NJ) was used as a standard. The gel was incubated in a humidified chamber at $37^{\circ} \mathrm{C}$ for 17 hours and was photographed under UV illumination.

\section{Denaturing SDS-PAGE Zymography}

DNasel activity in the kidneys, livers, and sera was determined after protein separation in a 10\% SDS-polyacrylamide gel containing $40 \mu \mathrm{g} / \mathrm{mL}$ of heat-denatured salmon sperm DNA (Invitrogen, Carlsbad, CA) as described elsewhere. ${ }^{25}$

\section{Native PAGE Zymography}

To analyze DNasel in spleens, we also performed the more sensitive native PAGE zymography instead of SDSPAGE. ${ }^{16}$ DNasel activity was determined after protein separation in $7.5 \%$ polyacrylamide gels containing $30 \mu \mathrm{g} / \mathrm{mL}$ of heat-denatured salmon sperm DNA (Invitrogen) as described in detail elsewhere. ${ }^{16,17}$ Liver samples were analyzed by SDS-PAGE and native PAGE zymographies, and both techniques demonstrated similar results in liver tissue.

\section{Statistical Analysis}

One-way analysis of variance with Dunnett's post hoc test was used in this study. Differences were considered significant at $P<0.05$.

\section{Results}

\section{Analyses of Serum dsDNA-Specific Antibodies and Renal and Liver Morphologic Characteristics in BW Mice}

To investigate the DNasel mRNA level and enzyme activity in different organs of BW mice, we divided female BW mice into three groups according to age, DNA-specific antibody titer, and disease severity (Table 1). Group 1 represents young, nonproteinuric, dsDNA-specific antibody-negative BW mice. IEM analysis of corresponding kidney sections did not demonstrate any morphologic changes (Figure 1 and Table 1). Group 2 is composed of nonproteinuric animals with variable titers of serum dsDNA-specific antibody and deposits of ICs, seen as electron-dense structures (EDSs) containing IgG in the glomerular mesangial matrix (Figure 1 and Table 1). Nephritic BW mice with severe proteinuria, circulating dsDNA-specific antibodies, and EDSs with IgG in the mesangial matrix and in GBMs represent group 3 (Figure 1 and Table 1). Liver tissue of animals from each group was also analyzed by IEM. We did not find any immune deposits or EDSs in liver capillary and arterial walls in any of the mice included in this study (Table 1 and Figure 1). Sex- and age-matched BALB/c mice were used as control mice. They were all negative for DNA-specific antibodies and did not have any immune deposits in kidneys or livers (data not shown).

\section{DNasel Expression in Kidneys, Livers, Spleens, and Sera of BW Mice}

Relative DNasel gene expression levels in different organs from mice in groups 1 to 3 were analyzed by realtime PCR, corresponding enzyme activity, and protein expression. mRNA levels of DNasel (columns) and enzyme activity (gels) in individual mice were determined in kidneys, livers, and spleens (Figure 2, A-C).

DNasel mRNA is normally expressed in prenephritic kidneys (group 1; Figure 2A) and in kidneys from mice with mesangial nephritis (group 2; Figure 2A); however, DNasel mRNA is dramatically reduced in kidneys from 
Table 1. Laboratory Variables and Morphologic Characteristics of BW Mice Included in This Study

\begin{tabular}{|c|c|c|c|c|c|c|c|}
\hline \multirow{2}{*}{$\begin{array}{l}\text { Mouse } \\
\text { group no. }\end{array}$} & \multirow{2}{*}{$\begin{array}{l}\text { Mouse } \\
\text { no. }\end{array}$} & \multirow{2}{*}{$\begin{array}{c}\text { Age } \\
\text { (weeks) }\end{array}$} & \multirow{2}{*}{$\begin{array}{c}\text { Anti-DNA } \\
\text { antibody titer }\end{array}$} & \multirow[b]{2}{*}{ Proteinuria* } & \multicolumn{3}{|c|}{ EDSs } \\
\hline & & & & & MM & GBM & Liver \\
\hline \multirow[t]{3}{*}{1} & 1 & 12 & 0 & - & - & - & - \\
\hline & 2 & 12 & 0 & - & - & - & - \\
\hline & 3 & 12 & 0 & - & - & - & - \\
\hline \multirow[t]{3}{*}{2} & 4 & 30 & 100 & $1+$ & + & - & - \\
\hline & 5 & 30 & 1400 & - & + & - & - \\
\hline & 6 & 30 & 3000 & - & + & - & - \\
\hline \multirow[t]{6}{*}{3} & 7 & 32 & 800 & $4+$ & + & + & - \\
\hline & 8 & 26 & 200 & $4+$ & + & + & - \\
\hline & 9 & 32 & 200 & $4+$ & + & + & - \\
\hline & 10 & 27 & 500 & $4+$ & + & + & - \\
\hline & 11 & 24 & 400 & $4+$ & + & + & - \\
\hline & 12 & 24 & 400 & $4+$ & + & + & - \\
\hline
\end{tabular}

*Proteinuria was determined by urine stix: 0 to $1+, \geq 0.3 \mathrm{~g} / \mathrm{L}$ (regarded as physiologic proteinuria); $2+, \geq 1 \mathrm{~g} / \mathrm{L} ; 3+, \geq 3 \mathrm{~g} / \mathrm{L} ;$ and $4+, \geq 20 \mathrm{~g} / \mathrm{L}$. GBM, glomerular basement membrane; MM, mesangial matrix.

group 3 BW mice (Figure 2A). The low DNasel mRNA level in group 3 mice is also reflected by low enzyme activity as determined by zymography (Figure 2A) and by weak protein expression in kidneys as determined by $\mathrm{IHC}$ analysis (Figure 2E). Low DNasel expression was presented uniformly in glomeruli and tubuli in kidney sections from group 3 mice.

To analyze whether silencing of the DNasel gene in nephritic BW mice is an organ-specific feature, mRNA levels were determined in livers and spleens of the same BW mice. The data demonstrate that DNasel mRNA expression is not reduced in livers (Figure 2B) or in spleens (Figure 2C) from all groups of mice. These results compare well with assays on DNasel enzyme activity as analyzed by gel zymography (Figure 2, B and C, for livers and spleens, respectively) and IHC analysis of livers for DNasel protein expression in situ (Figure 2E). DNasel mRNA level and enzyme activity in livers in group 2 and in spleens in groups 2 and 3 tended to be higher compared with group 1 results (Figure 2, B and C, for livers and spleens, respectively). This finding was statistically significant, however, only for DNasel mRNA levels in spleens from group 2 mice. IHC analysis of DNasel on liver sections reflects the results of DNasel mRNA levels (Figure 2E). Quantification of the staining intensity of DNasel in kidney and liver sections of BW mice demonstrates loss of DNase I in kidneys but not in livers (see Supplemental Figure S1 at http://ajp.amjpathol.org).
The data in Figure 2D demonstrate no reduction in serum DNasel enzyme activity, as determined in group 3 compared with group 1 and 2 mice. Zymograms of serum samples exhibit a pattern similar to that seen in zymograms of liver lysates, in agreement with a report showing that liver is a main source of serum DNasel. ${ }^{16}$

The mRNA level and enzyme activity of renal DNasel in age- and sex-matched BALB/c mice are presented in Supplemental Figure S2A (available at http://ajp. amjpathol.org). As demonstrated, DNasel is expressed at stable levels in all groups of control animals. Delta $C_{T}$ values and calculated fold changes of renal DNasel mRNA levels in examined groups of BW and BALB/C mice are shown in Supplemental Table S1 (available at http://ajp.amjpathol.org).

\section{Total Nuclease Activity in Kidneys, Livers, Spleens, and Sera of BW Mice}

Results of DNasel zymography led us to analyze whether DNasel levels affect total nuclease activity in kidneys, livers, spleens, and sera of BW mice during progression of lupus nephritis. We observed nuclease activity, as determine by a single radial diffusion nuclease assay, in kidneys, livers, spleens, and sera at different stages of the disease (Figure 3). Calculated group mean \pm SD values are given as insets in each

\section{Group 1}

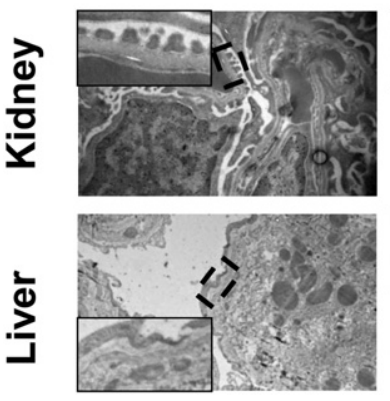

Group 2

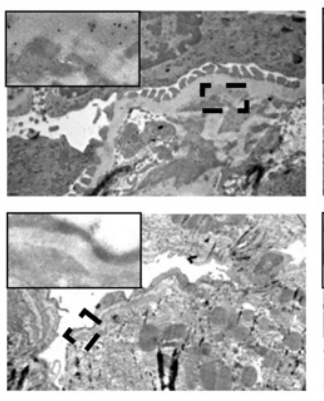

Group 3

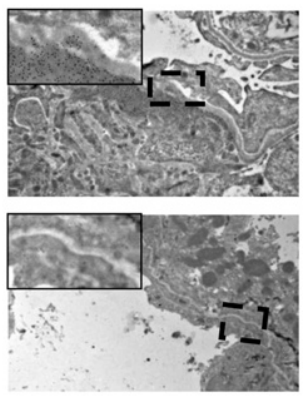

Figure 1. IEM analyses of EDSs in kidneys and livers from BW mice at different stages of lupus nephritis. BW mice were divided into three groups according to kidney morphologic features (top panels): group 1, mice without EDSs in glomeruli; group 2, animals with EDSs in mesangium; and group 3 , mice with EDSs in the mesangial matrix and in GBMs. In vivo-bound IgGs are traced by 5 -nm gold particles. No EDSs were found, however, in arterial or capillary walls in corresponding liver sections in BW mice in groups 1 to 3 (bottom panels). Insets: Magnified areas of basement membranes included in the dashed boxes. 

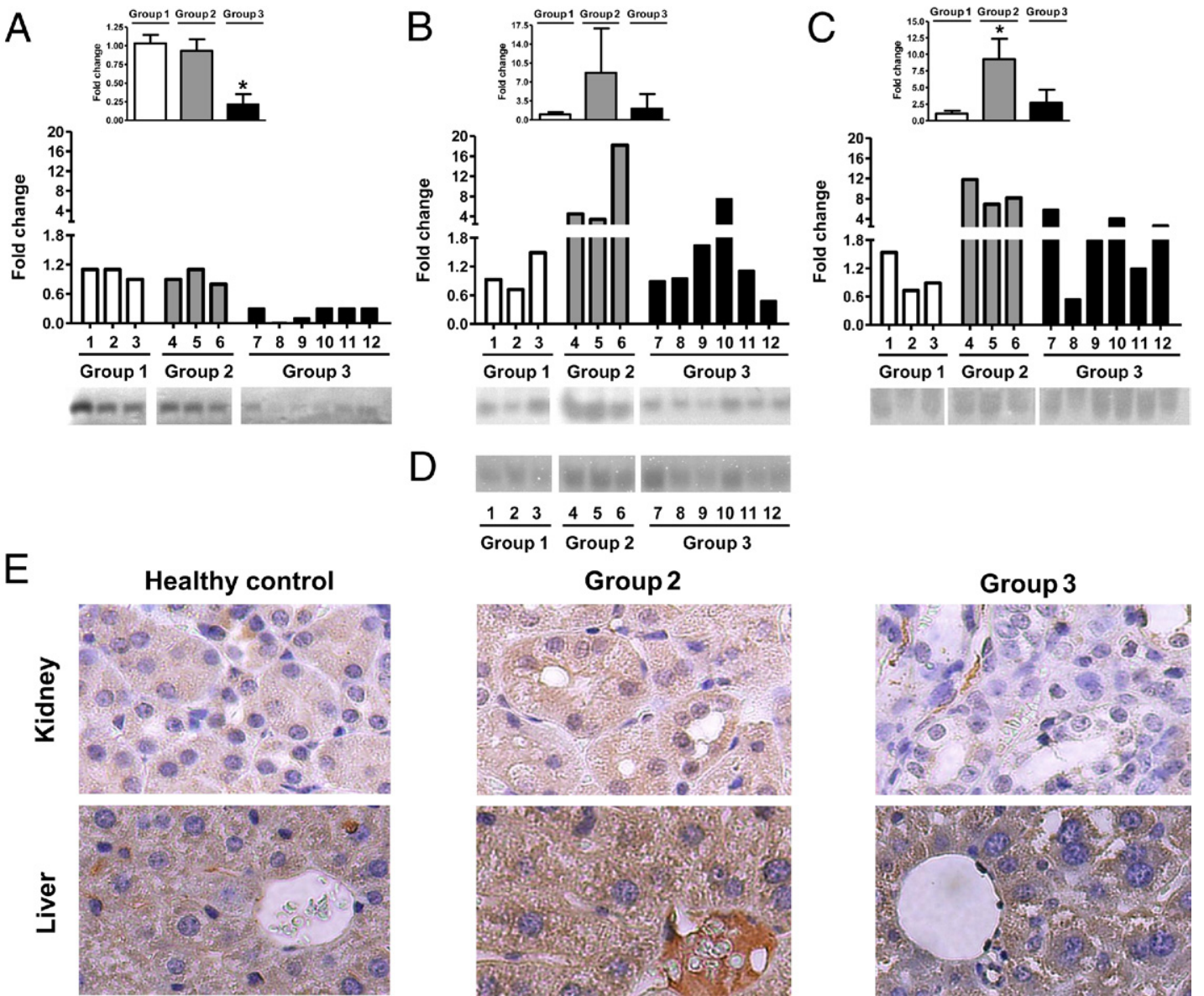

Figure 2. DNaseI expression in organs and sera of BW mice at different stages of lupus nephritis. The mRNA levels (columns) and enzyme activity (gels) of DNasel are determined in kidneys $(\mathbf{A})$, livers $(\mathbf{B})$, and spleens $(\mathbf{C})$ of individual BW mice in prenephritic group 1 mice and in mice with mesangial nephritis (group 2) or with membranoproliferative nephritis (group 3). Insets: Mean \pm SD DNaseI mRNA levels in each group for each organ. ${ }^{*} P<0.05$ versus group 1 . The mRNA levels of DNasel in livers and spleens of BW mice with severe nephritis (group 3) are not reduced, whereas they are dramatically low in kidneys of the same animals. The enzyme activity of DNaseI measured by SDS-PAGE zymography for kidneys and livers and by native PAGE zymography for spleens correlates well with results of mRNA levels. D: The DNaseI activity in sera of individual BW mice in the different groups of lupus nephritis, as measured by SDS-PAGE zymography, is similar to the expression patterns of DNaseI activity in livers and is not reduced in group $3 \mathrm{BW}$ mice. E: IHC analyses of DNaseI expression in kidney (top panels) and liver (bottom panels) sections in group 2 and $3 \mathrm{BW}$ mice is demonstrated compared with expression in age-matched controls. Expression of DNaseI in tubular cells of BW mice with severe nephritis (group 3) is nearly undetectable, whereas it is normally present in liver sections in the same animals. Original magnification, $\times 200$.

panel. The results demonstrate that there is no decrease in total nuclease activity among groups 1,2, and 3 in livers or spleens of BW mice, whereas total nuclease activity in kidneys of animals with severe nephritis (group 3) is markedly reduced compared with that in mice from groups 1 and 2. In serum samples (Figure 3D), total nuclease activity was not reduced during lupus nephritis progression, similar to the re-
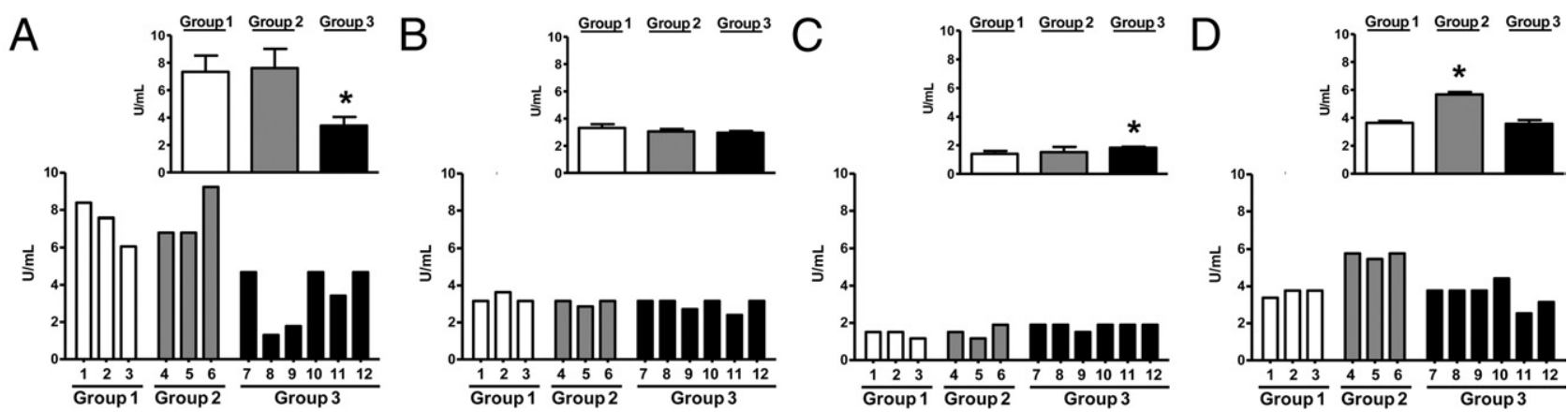

Figure 3. Total nuclease activity in organs and sera of BW mice at different stages of lupus nephritis. Nuclease activity in kidney (A), liver (B), spleen (C), and serum (D) samples of individual BW mice (bottom row) is measured by a single radial diffusion nuclease assay. Top row: Mean \pm SD of total nuclease activity in each group for each organ. ${ }^{*} P<0.05$ versus group 1 . In kidneys only, nuclease activity is markedly reduced in group 3 BW mice. Data are given as DNaseI unit equivalents. 

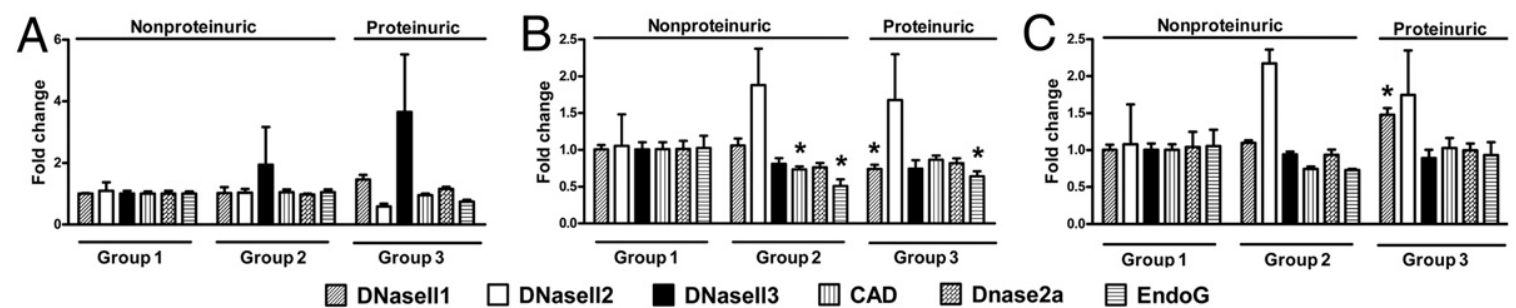

Figure 4. Expression profiles of DNaseII1 to 3, CAD, Dnase2a, and EndoG in BW mice during progression of lupus nephritis. The mRNA levels of different nucleases are determined in kidney $(\mathbf{A})$, liver $(\mathbf{B})$, and spleen $(\mathbf{C})$ samples in prenephritic group 1 mice, in mice with mesangial nephritis (group 2), and in mice with membranoproliferative lupus nephritis (group 3). Values are given as mean \pm SD. ${ }^{*} P<0.05$ versus group 1 . No significant changes in transcription levels of DNaseII1 to 3, CAD, Dnase2a, and EndoG were observed in kidneys in BW mice at different stages of lupus nephritis.

sults of DNasel zymography on serum samples shown in Figure 2D.

\section{Expression Profiles of Other Nucleases in Kidneys, Livers, and Spleens from Group 1 to 3 BW Mice}

We measured gene expression levels of other endonucleases by real-time PCR applied to kidneys, livers, and spleens to analyze for two possible phenomena: selectivity of DNasel down-regulation compared with the other nucleases and possible compensatory changes of other nucleases in all three organs in situations where the important renal DNasel gene is shut down. Figure 4 demonstrates mRNA levels of DNasell1 to 3, CAD, Dnase2a, and EndoG in kidneys, livers, and spleens of BW mice in groups 1 to 3 . The mean of each nuclease mRNA level in each group of mice is presented for each organ. No significant difference is found in the transcriptional levels of any of the nucleases in kidneys, livers, or spleens, except for those indicated by an asterisk in Figure 4, B and $\mathrm{C}$, compared with prenephritic (group 1) mice. IHC analysis performed on kidney (Figure 5A) and liver (Figure $5 \mathrm{~B}$ ) sections confirmed the results of real-time PCR on $\mathrm{CAD}$ and EndoG, as the staining intensity was consistently similar in all groups of mice. Quantitative scoring analysis of staining intensity of CAD and EndoG on kidney and liver sections showed stable expression throughout the observation period (see Supplemental Figure S1, $A$ and $B$, respectively, at http://ajp.amjpathol.org). Expression profiles of renal DNasell1 to 3, CAD, Dnase2a, and EndoG in age- and sex-matched BALB/c mice showed largely stable values for all endonucleases studied throughout the observation period (see Supplemental Figure S2B at http://ajp.amjpathol.org).

\section{Discussion}

The role of decreased DNasel in the pathogenesis of SLE has been discussed for decades. DNasel was seen as a promising target for substitutive therapy to prevent autoimmunity, ${ }^{26}$ but it has been discredited after insufficient results of the trial treatment. ${ }^{27}$ In a single study by Macanovic et al, ${ }^{26}$ injection of DNasel in prenephritic BW mice postponed the disease, whereas treating nephritic animals decreased levels of proteinuria and serum cre- atinine. However, these observations were not followed by further penetrating studies that would have provided insight into the therapeutic effect of DNasel treatment. In another study, administration of DNasel in BW mice did not affect development or progression of lupus nephritis. ${ }^{28}$ Similarly, intravenous or subcutaneous administration of recombinant human DNasel in patients with lupus nephritis classes III to V did not show any effect on kidney function or activity of the disease. ${ }^{27}$ This finding may signify that serum DNasel has little or no influence on degradation of chromatin in dying renal cells. ${ }^{29}$ Only intracellular renal DNasel initiates and ensures a safe and effective degradation of chromatin in dying cells in the kidneys. $^{29}$

Tubular cells dominate among renal cells that express DNasel (Figure 2E), ${ }^{9,15,30}$ but DNasel is also expressed in mesangial cells (N. Seredkina, unpublished data). ${ }^{15}$ Detection of apoptotic cells in kidney sections demonstrated that tubular and glomerular cells undergo apoptosis. ${ }^{10,11,21}$ Reduced DNasel expression is furthermore
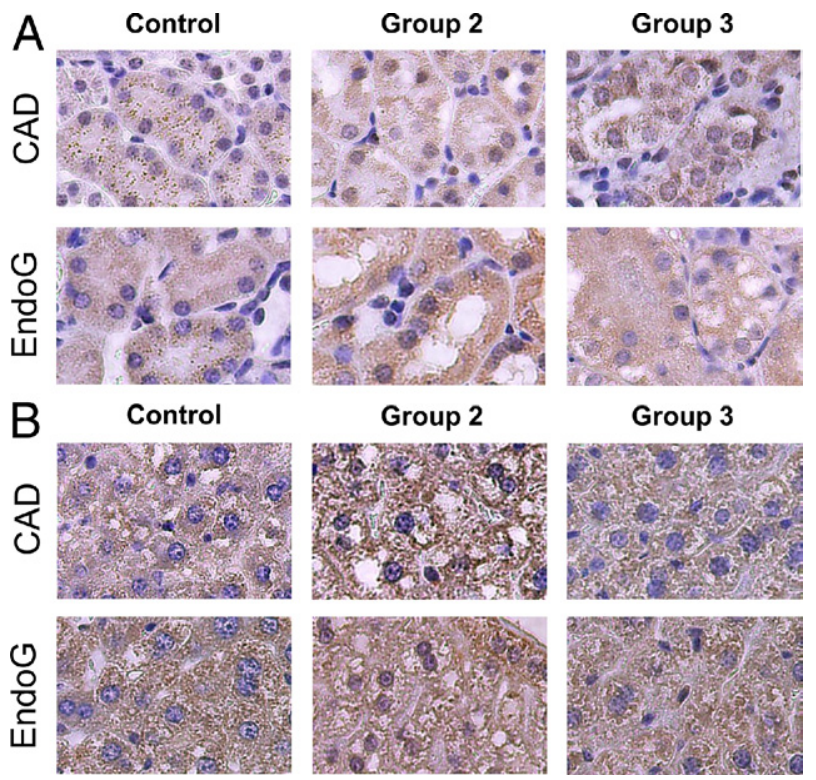

Group 2

Group 3
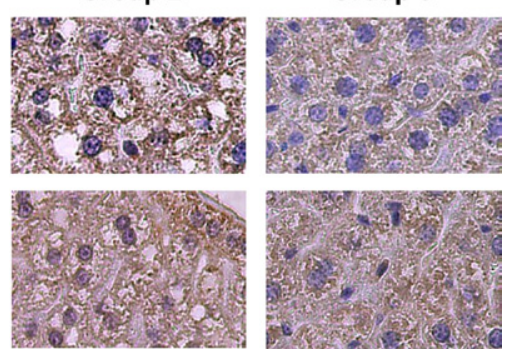

Figure 5. IHC analyses of $C A D$ and EndoG in kidneys (A) and livers (B) from BW mice. Expression of CAD (top panels) and EndoG (bottom panels) proteins was determined in kidney (A) and liver (B) sections of BW mice in groups 2 and 3 and compared with data obtained in BALB/c control mice. No difference in nuclease expression was observed in organs of BW mice with severe nephritis compared with control animals. Original magnification, $\times 200$ 
observed uniformly in glomerular and tubular cells in BW mice with severe nephritis. ${ }^{15}$ An acquired loss of renal DNasel in lupus nephritis may, therefore, be the event that results in reduced chromatin fragmentation in a dominant proportion of renal cells, resulting in exposure of large chromatin fragments in the kidneys. Such fragments participate in the formation of ICs in GBM and, thus, account for progression of lupus nephritis into endstage organ disease.

To better understand the role of DNasel expression in progressive lupus nephritis, it became important to determine three aspects of this phenomenon: i) Is shutdown of renal DNasel unique to DNasel, or do other renal nucleases behave in a similar manner? ii) Is renal DNasel shutdown unique to kidneys, or is DNasel down-regulated in other organs as well? iii) Are other nucleases up-regulated in compensation in situations where DNasel is lost in the kidneys?

Data in the present study provide answers that explain all these aspects. For the first, data confirm that renal DNasel is lost when lupus nephritis transforms mild into severe membranoproliferative organ disease. ${ }^{8,15}$ In expression profiles of seven nucleases analyzed in kidneys, livers, and spleens, highly reduced nuclease expression is restricted to DNasel, in agreement with a recent preliminary observation. ${ }^{15}$ Furthermore, the DNasel shutdown was restricted to the kidneys of BW mice with severe nephritis because expression seemed normal in livers and spleens of the same individual animals. No clear tendency for compensatory up-regulation of other nucleases involved in chromatin degradation was observed in livers and kidneys, whereas DNasell1 was slightly up-regulated in spleens of group $3 \mathrm{BW}$ mice.

Serum DNasel activity in the different groups of mice correlated with DNasel activity in the liver but not in the kidney, in accordance with other results. ${ }^{16}$ There are several reports about reduced serum DNasel activity in patients with SLE ${ }^{31-34}$ and in lupus-prone mice. ${ }^{14,15}$ All of those analyses are based on measurement of nuclease activity in sera by radial diffusion assay, which is a sensitive but not a DNasel-specific method. Published data indicating the correlation of serum DNasel activity with activity of SLE or with renal involvement in SLE remain, however, controversial. The first study, by Chitrabamrung et $\mathrm{al}^{31}{ }^{31}$ of 36 patients with SLE demonstrated that individuals with active lupus (including active lupus nephritis) had the lowest levels of enzymatic activity compared with those in healthy volunteers or in patients with rheumatoid arthritis and scleroderma. This observation was challenged by Sallai et $\mathrm{al}^{33}{ }^{33}$ who demonstrated that serum DNasel did not correlate with disease activity in 113 patients with SLE with or without lupus nephritis. Moreover, activity of serum DNasel in patients with SLE was not reduced compared with enzymatic activity in patients with undifferentiated connective tissue disease. ${ }^{33}$ Data in the present study demonstrate that total serum nuclease activity, and selective serum DNasel activity, was not reduced in BW mice during progression of lupus nephritis. Thus, serum DNasel may not be important for the kidneys in a situation where renal DNasel is lost. This may also explain why injection of DNasel does not affect the activity of lupus nephritis in patients. ${ }^{27}$ This leaves us with the perception that renal intracellular DNasel is required for safe degradation and elimination of chromatin from dying renal cells. Without this enzyme, chromatin degradation is impaired and large chromatin fragments accumulate in situ, where they are released from dying cells. This may, indeed, be one of the factors that results in impaired clearance of apoptotic secondary necrotic cell debris. ${ }^{35-38}$

We found increased DNasel mRNA expression and enzyme activity in liver and spleen in the early and late stages of lupus nephritis. The observed increase in DNasel expression in those organs was associated with high titers of dsDNA-specific antibodies in serum. Because one common function of liver and spleen is uptake of circulating ICs, we assume that DNasel participates in chromatin degradation of cleared ICs. This may eventually explain increased DNasel expression in these organs.

Selective loss of renal DNasel creates a basis for in situ deposition of chromatin, a phenomenon independently demonstrated in different experimental nuclease deficiencies. In several such studies, it is demonstrated that chromatin fragments accumulate in situ, where they are released from dead cells, ${ }^{39}$ instead of entering the circulation.

The present results add weight to the assumption that DNasel shutdown is secondary to early dsDNA-specific antibody-mediated deposition of ICs in the mesangial matrix. ${ }^{8}$ This may mean that inflammation linked to (silent or mild) mesangial nephritis in fact imposes the loss of renal DNasel, with the consequences for renal function as described herein. This proposed mechanism is in agreement with results of high-resolution techniques to determine the nature of target structures in the glomeruli. These structures appear as EDSs by transmission electron microscopy and are composed of chromatin fragments and lgG molecules, as determined by different forms of IEM and by co-localization TUNEL IEM assay. ${ }^{40-42}$

Comparative studies of components and localization of EDSs in skin and glomeruli in SLE demonstrated that they are composed of similar chromatin-related structures. $^{43,44}$ Deposition of ICs in glomeruli did not, however, predict deposition in skin. ${ }^{43,44}$ Examination of DNasel expression in skin of MRL-Ipr/lpr and BW mice revealed stable DNasel activity during the development of lupus nephritis. ${ }^{44}$ Those results indicate that chromatin in chromatin-IgG complexes that deposit in skin have another origin than from skin itself. In harmony with this, published data demonstrate the presence of polyomovirus large T antigen in extracellular chromatin associated with glomerular and skin membranes, ${ }^{43}$ suggesting that chromatin fragments in kidneys and skin might derive from polyomavirus-infected renal cells because renal polyomavirus infection is a frequent finding in patients with lupus nephritis. ${ }^{22}$ Further investigations are needed to confirm whether chromatin fragments found in skin EDSs of patients with SLE may have a renal origin.

The precise mechanism by which the expression of renal DNasel shuts down is unknown but is currently being analyzed in the Molecular Pathology Laboratory at the University of Tromsø. Contemporarily, we are following three lines of analyses: i) transcriptional interference 
with a convergently encoded gene (Trap1) that overlaps with the DNasel gene in their 3' untranslated region and ii) regulation by microRNAs or iii) by DNA methylation. The initial event accounting for DNasel shutdown may, however, represent a response to inflammatory signals provided by the early mesangial nephritis. This would be in favor of transcriptional interference with the Trap1 gene because Trap1 is up-regulated during stress and inflammation. ${ }^{45,46}$ Therefore, we currently perform in vitro studies using cultures of primary mesangial and tubular cells exposed to autoantibodies, nucleosomes, ICs, and proinflammatory cytokines to determine the impact of the inflammatory mesangial nephritis environment on DNasel expression in renal cells. We also analyze the impact of albumin overload on the ability of tubular cells to express DNasel because its contribution to renal proximal cell apoptosis has been reported. ${ }^{47,48}$ Furthermore, microRNAs that target DNasel mRNA have been identified in the mesangial nephritis and in end-stage organ disease in the Molecular Pathology Laboratory at the University of Tromsø (studies in progress).

From the data presented herein, adding to previous results, $8,10,11,15$ we may conclude that the processes accounting for transformation of mild mesangial nephritis into severe end-stage organ disease is linked to events in the kidneys and is selective for the kidneys. This event is regulated by renal DNasel shutdown.

\section{References}

1. Tan EM: Autoantibodies to nuclear antigens (ANA): their immunobiology and medicine. Adv Immunol 1982, 33:167-240

2. Herrmann M, Winkler T, Gaipl U, Lorenz H, Geiler T, Kalden JR: Etiopathogenesis of systemic lupus erythematosus. Int Arch Allergy Immunol 2000, 123:28-35

3. Nossent JC, Bronsveld W, Swaak AJ: Systemic lupus erythematosus, III: observations on clinical renal involvement and follow up of renal function: Dutch experience with 110 patients studied prospectively. Ann Rheum Dis 1989, 48:810-816

4. Clynes R, Dumitru C, Ravetch JV: Uncoupling of immune complex formation and kidney damage in autoimmune glomerulonephritis. Science 1998, 279:1052-1054

5. Davidson A, Aranow C: Lupus nephritis: lessons from murine models. Nat Rev Rheumatol 2010, 6:13-20

6. Appel GB, Valeri A: The course and treatment of lupus nephritis. Annu Rev Med 1994, 45:525-537

7. Berden JH: Lupus nephritis. Kidney Int 1997, 52:538-558

8. Fenton K, Fismen S, Hedberg A, Seredkina N, Fenton C, Mortensen ES, Rekvig OP: Anti-dsDNA antibodies promote initiation, and acquired loss of renal Dnase1 promotes progression of lupus nephritis in autoimmune (NZBXNZW)F1 mice. PLoS One 2009, 4:e8474

9. Basnakian AG, Apostolov EO, Yin X, Napirei M, Mannherz HG, Shah SV: Cisplatin nephrotoxicity is mediated by deoxyribonuclease I. J Am Soc Nephrol 2005, 16:697-702

10. Seredkina N, Zykova SN, Rekvig OP: Progression of murine lupus nephritis is linked to acquired renal Dnase 1 deficiency and not to up-regulated apoptosis. Am J Pathol 2009, 175:97-106

11. Zykova SN, Seredkina N, Benjaminsen J, Rekvig OP: Reduced fragmentation of apoptotic chromatin is associated with nephritis in lupusprone (NZB x NZW)F(1) mice. Arthritis Rheum 2008, 58:813-825

12. Ogawa Y, Yoshinaga T, Yasuda K, Nishikawa M, Takakura Y: The uptake and degradation of DNA is impaired in macrophages and dendritic cells from NZB/W F(1) mice. Immunol Lett 2005, 101:32-40

13. Tveita AA, Rekvig OP, Zykova SN: Increased glomerular matrix metalloproteinase activity in murine lupus nephritis. Kidney Int 2008, $74: 1150-1158$
14. Macanovic M, Lachmann PJ: Measurement of deoxyribonuclease I (DNase) in the serum and urine of systemic lupus erythematosus (SLE)-prone NZB/NZW mice by a new radial enzyme diffusion assay. Clin Exp Immunol 1997, 108:220-226

15. Zykova SN, Tveita AA, Rekvig OP: Renal Dnase 1 enzyme activity and protein expression is selectively shut down in murine and human membranoproliferative lupus nephritis. PLoS One 2010, 5:e12096

16. Ludwig S, Mannherz HG, Schmitt S, Schaffer M, Zentgraf H, Napirei M: Murine serum deoxyribonuclease 1 (Dnase1) activity partly originates from the liver. Int J Biochem Cell Biol 2009, 41:1079-1093

17. Napirei M, Ricken A, Eulitz D, Knoop H, Mannherz HG: Expression pattern of the deoxyribonuclease 1 gene: lessons from the Dnase 1 knockout mouse. Biochem J 2004, 380:929-937

18. Takeshita H, Mogi K, Yasuda T, Nakajima T, Nakashima Y, Mori S, Hoshino T, Kishi K: Mammalian deoxyribonucleases I are classified into three types: pancreas, parotid, and pancreas-parotid (mixed), based on differences in their tissue concentrations. Biochem Biophys Res Commun 2000, 269:481-484

19. Davies KA, Erlendsson K, Beynon HL, Peters AM, Steinsson K, Valdimarsson $\mathrm{H}$, Walport MJ: Splenic uptake of immune complexes in man is complement-dependent. J Immunol 1993, 151:3866-3873

20. Skogh T, Blomhoff R, Eskild W, Berg T: Hepatic uptake of circulating IgG immune complexes. Immunology 1985, 55:585-594

21. Kalaaji M, Mortensen E, Jorgensen L, Olsen R, Rekvig OP: Nephritogenic lupus antibodies recognize glomerular basement membraneassociated chromatin fragments released from apoptotic intraglomerular cells. Am J Pathol 2006, 168:1779-1792

22. Rekvig OP, Moens U, Sundsfjord A, Bredholt G, Osei A, Haaheim H, Traavik T, Arnesen E, Haga HJ: Experimental expression in mice and spontaneous expression in human SLE of polyomavirus T-antigen: a molecular basis for induction of antibodies to DNA and eukaryotic transcription factors. J Clin Invest 1997, 99:2045-2054

23. Richardsen E, Ukkonen T, Bjornsen T, Mortensen E, Egevad L, Busch C: Overexpression of IGBFB2 is a marker for malignant transformation in prostate epithelium. Virchows Arch 2003, 442:329-335

24. Chitrabamrung S, Bannett JS, Rubin RL, Tan EM: A radial diffusion assay for plasma and serum deoxyribonuclease I. Rheumatol Int 1981, 1:49-53

25. Rosenthal AL, Lacks SA: Nuclease detection in SDS-polyacrylamide gel electrophoresis. Anal Biochem 1977, 80:76-90

26. Macanovic M, Sinicropi D, Shak S, Baughman S, Thiru S, Lachmann PJ: The treatment of systemic lupus erythematosus (SLE) in NZB/W F1 hybrid mice: studies with recombinant murine DNase and with dexamethasone. Clin Exp Immunol 1996, 106:243-252

27. Davis JC Jr, Manzi S, Yarboro C, Rairie J, Mcinnes I, Averthelyi D, Sinicropi D, Hale VG, Balow J, Austin H, Boumpas DT, Klippel JH: Recombinant human Dnase I (rhDNase) in patients with lupus nephritis. Lupus 1999, 8:68-76

28. Verthelyi D, Dybdal N, Elias KA, Klinman DM: DNAse treatment does not improve the survival of lupus prone (NZB $\times$ NZW)F1 mice. Lupus 1998, 7:223-230

29. Samejima K, Earnshaw WC: Trashing the genome: the role of nucleases during apoptosis. Nat Rev Mol Cell Biol 2005, 6:677-688

30. Buzder T, Yin X, Wang X, Banfalvi G, Basnakian AG: Uptake of foreign nucleic acids in kidney tubular epithelial cells deficient in proapoptotic endonucleases. DNA Cell Biol 2009, 28:435-442

31. Chitrabamrung S, Rubin RL, Tan EM: Serum deoxyribonuclease I and clinical activity in systemic lupus erythematosus. Rheumatol Int 1981, 1:55-60

32. Martinez-Valle F, Balada E, Ordi-Ros J, Bujan-Rivas S, Sellas-Fernandez A, Vilardell-Tarres M: DNase1 activity in systemic lupus erythematosus patients with and without nephropathy. Rheumatol Int 2010, 30:1601-1604

33. Sallai K, Nagy E, Derfalvy B, Muzes G, Gergely P: Antinucleosome antibodies and decreased deoxyribonuclease activity in sera of patients with systemic lupus erythematosus. Clin Diagn Lab Immunol 2005, 12:56-59

34. Martinez-Valle F, Balada E, Ordi-Ros J, Bujan-Rivas S, Sellas-Fernan$\operatorname{dez} \mathrm{A}$, Vilardell-Tarres M: DNase 1 activity in patients with systemic lupus erythematosus: relationship with epidemiological, clinical, immunological and therapeutical features. Lupus 2009, 18:418-423

35. Dieker JW, van der Vlag J, Berden JH: Deranged removal of apoptotic cells: its role in the genesis of lupus. Nephrol Dial Transplant 2004, 19:282-285 
36. Gaipl US, Kuhn A, Sheriff A, Munoz LE, Franz S, Voll RE, Kalden JR, Herrmann M: Clearance of apoptotic cells in human SLE. Curr Dir Autoimmun 2006, 9:173-187

37. Licht R, Dieker JW, Jacobs CW, Tax WJ, Berden JH: Decreased phagocytosis of apoptotic cells in diseased SLE mice. J Autoimmun 2004, 22:139-145

38. Munoz LE, Janko C, Schulze C, Schorn C, Sarter K, Schett G, Herrmann M: Autoimmunity and chronic inflammation: two clearancerelated steps in the etiopathogenesis of SLE. Autoimmun Rev 2010 10:38-42

39. Fismen S, Mortensen ES, Rekvig OP: Nuclease deficiencies promote end-stage lupus nephritis but not nephritogenic autoimmunity in (NZB x NZW) F1 mice. Immunol Cell Biol 2011, 89:90-99

40. Kalaaji M, Fenton KA, Mortensen ES, Olsen R, Sturfelt G, Alm P Rekvig OP: Glomerular apoptotic nucleosomes are central target structures for nephritogenic antibodies in human SLE nephritis. Kidney Int 2007, 71:664-672

41. Malide D, Londono I, Russo P, Bendayan M: Ultrastructural localization of DNA in immune deposits of human lupus nephritis. Am J Pathol 1993, 143:304-311

42. Mjelle JE, Rekvig OP, Fenton KA: Nucleosomes possess a high affinity for glomerular laminin and collagen IV and bind nephritogenic antibodies in murine lupus-like nephritis. Ann Rheum Dis 2007, 66:1661-1668
43. Fismen S, Hedberg A, Fenton KA, Jacobsen S, Krarup E, Kamper AL, Rekvig OP, Mortensen ES: Circulating chromatin-anti-chromatin antibody complexes bind with high affinity to dermo-epidermal structures in murine and human lupus nephritis. Lupus 2009, 18:597-607

44. Hedberg A, Fismen S, Fenton KA, Mortensen ES, Rekvig OP: Deposition of chromatin-IgG complexes in skin of nephritic MRL-Ipr/lpr mice is associated with increased local matrix metalloprotease activities. Exp Dermatol 2010, 19:e265-e274

45. Montesano GN, Chirico G, Pirozzi G, Costantino E, Landriscina M, Esposito F: Tumor necrosis factor-associated protein 1 (TRAP-1) protects cells from oxidative stress and apoptosis. Stress 2007, 10: 342-350

46. Takemoto K, Miyata S, Takamura H, Katayama T, Tohyama M: Mitochondrial TRAP1 regulates the unfolded protein response in the endoplasmic reticulum. Neurochem Int 2011, 58:880-887

47. Ohse T, Inagi R, Tanaka T, Ota T, Miyata T, Kojima I, Ingelfinger JR, Ogawa S, Fujita T, Nangaku M: Albumin induces endoplasmic reticulum stress and apoptosis in renal proximal tubular cells. Kidney Int 2006, 70:1447-1455

48. Wu X, He Y, Jing Y, Li K, Zhang J: Albumin overload induces apoptosis in renal tubular epithelial cells through a CHOP-dependent pathway. OMICS 2010, 14:61-73 